\title{
Nonhuman Animal Rights, Alternative Food Systems, and the Non-Profit Industrial Complex
}

\author{
Corey Lee WrenN
}

\section{Introduction}

In response to concerns over the treatment of animals in the food industry, the humane product movement and welfare-focused Nonhuman Animal ${ }^{1}$ advocacy have arisen to create an alternate system of food production, one that has gained significant attention in the past 30 years (Singer and Mason 4). The industry-led humane product movement seeks to capitalize on public concern with Nonhuman Animal welfare in improving the "humaneness" of their products. The Nonhuman Animal advocacy movement seeks to address concerns with welfare by advocating industry reform. Ultimately, these shared goals mean that the two parties often cooperate for mutual benefit. As neither position challenges the property status of other animals, this paper argues that neither position is properly equipped to extend moral consideration to Nonhuman Animals. This paper also suggests that the shortcomings of advocacy groups reflect a desire to cooperate with state and industry out of self interest, which necessitates that they compromise goals and marginalize radical alternatives to Nonhuman Animal exploitation.

Regardless of intents or interests, I argue that any alternative food system that remains based on Nonhuman Animal use is inherently problematic. The practices of animal-based alternative systems contradict the stated goals of industries and advocacy groups that purport to consider the rights or welfare of Nonhuman Animals. Use, exploitation, and death, which are 
inherent to both traditional and alternative food systems, are incompatible with any Nonhuman Animal rights or welfare ethic. Using the abolitionist Nonhuman Animal rights theory framework, it is argued that alternative agricultural systems maintain the property-status of other animals and this undermines any serious consideration for their well-being. This shortcoming is likely indicative of the non-profit industrial complex that encourages organizations to prioritize funding over radical social change (Smith 9). Such a compromise entails collaboration with industries and the state, which ultimately works to quell dissent and maintain oppressive social structures. This paper will also discuss potential compromises for alternative systems that would respect equal consideration for Nonhuman Animals, focusing on vegan grassroots activism as a necessary component for consistency and effectiveness.

\section{Modern Agricultural Food Systems and Their Alternatives}

The modern, industrialized food system has been increasingly criticized for its detriment to the welfare of Nonhuman Animals (Rollin, Animal Rights 332; Singer, Animal Liberation 95). Of the nine billion Nonhuman Animals (not including sea life, insect life, male discard chicks killed upon hatching, or other non-traditional livestock) slaughtered for human consumption in the United States (Grannis 4; United States Department of Agriculture, Chicken and Eggs 5; United States Department of Agriculture, Livestock Slaughter 6; United States Department of Agriculture, Poultry Slaughter 4$),{ }^{2}$ the vast majority are part of the modern industrial agricultural process (Steinfeld et al. 57). Modern industrial animal agriculture (also referred to as concentrated animal feed operations, intensive farming, or factory farming) is characterized by the confinement of large numbers of Nonhuman Animals within a small area (Nierenberg \& Garcés 4). Chickens, pigs, cows, sheep, turkeys, ducks, and other Nonhuman Animals who are 
part of this modern system endure routine "artificial insemination," ${ }^{4}$ ill-effects of genetic modification, multiple pregnancies, forced molting, forced feedings and unnatural diets, lack of fresh air and sunlight, crowding, disease, and lack of mental stimulation. They also undergo dehorning, debeaking, castration, tail docking, and tooth removal without the comforts of anesthesia (Singer, Animal Liberation 95). In transportation to slaughter, Nonhuman Animals in the modern system may go without food or water for days before and during transport. Animals in transport withstand crude handling, long transport times, and exposure to elements. They may or may not arrive at the slaughterhouse alive. Generally, the mass production of Nonhuman Animals in factory farming allows for significant losses while still garnering profit (Singer, Animal Liberation 95). Thousands of cows and pigs might arrive to slaughter lame or unable to stand or walk (Grandin 10). Stunning and slaughtering methods are not always effective, and many Nonhuman Animals enter boiling vats intended to remove fur or feathers or are butchered while still conscious (Singer and Mason 67). While these practices have become standard across the industry, the suffering of Nonhuman Animals (and the subsequent risks tortured and medicated Nonhuman Animal flesh poses to humans) has raised concerns.

Responding to criticisms of modern agricultural practices, the humane product movement has enjoyed considerable success in recent years (Gillespie 100). The push for humaneness in agricultural systems is an approach to Nonhuman Animal use which does not challenge the property status of Nonhuman Animals, but does address the ways in which those animals are treated. Labels such as "free-range," "grass-fed," "organic," "humanely-raised," "cage-free," etc. contend with consumer concerns with the treatment of Nonhuman Animals. The humane product movement purports to respect the telos of Nonhuman Animals, adhering to what "nature intended" (American Grassfed Association) and farming in "harmony with nature" while 
working with "animals' natural behaviors" (Organic Valley). They are also less likely to see death as a harm, as the actual killing of Nonhuman Animals is divorced from welfare considerations. As an example, Whole Foods Market recently introduced "Harpoon-Caught Swordfish" to their stores. A promotional image documenting the practice shows a dead fish sprawled upside down on a boat deck, impaled by a huge harpoon. The company's website also hosts a video documenting the gruesome deaths of these animals who are "handled with care" (Thompson 100). Strangely, in the footage they provide, the fish is pulled from the water already dead. Visitors do not see any pain or struggle, though harpooning is hardly a clean or painless death in most instances. Regardless, Whole Foods touts the practice as an especially humane one with a "low impact on ocean habitat" as it avoids accidentally killing other marine life or immature swordfish. Indeed, in describing the amazing recovery of swordfish populations and the maintenance of "healthy fish populations and ecosystems," one might easily believe that purchasing these harpooned pieces of flesh are actually helping swordfish. If the use of Nonhuman Animals is understood as congruent with the telos of farmed Nonhuman Animals and they are thought not to be harmed by death, alternative systems would recognize no real contradiction in human moral obligation to Nonhuman Animals.

\section{Contradicting Goals of Nonhuman Animal Welfare}

Many have disagreed with this approach, arguing that the move towards "humaneness" does not benefit Nonhuman Animals as portrayed in the humane narrative (see for instance Cole 93-96; Francione, "The Abolition of Animal Exploitation"). Indeed, humane products vary dramatically in the levels of Nonhuman Animals maltreatment. Farm Sanctuary reports: "Various humane certification and labeling programs have been developed in response to 
growing popular concerns about the cruel treatment of farm animals, but their impact at improving animal welfare has been minimal" (Farm Sanctuary) Another Nonhuman Animal rights organization, Compassion over Killing, led several investigations into the Animal Care Certified labeling program and found considerable Nonhuman Animal abuse that was thought inconsistent with the goals of the program. Compassion over Killing determined the labeling to be fraudulent and launched a consumer fraud lawsuit in New Jersey in 2008 (Compassion over Killing). Farm Sanctuary's 2009 report on humane labeling found that such labeling was often vague and unenforced (Farm Sanctuary). ${ }^{5}$ Singer and Mason also discovered many loopholes in the labeling system that left Nonhuman Animals vulnerable (Singer and Mason 101). Major producers often had cows standing on bare earth with very little access to pasture. Chickens laying organic labeled eggs for a popular company were found living in cramped conditions with severely limited access to the outdoors. These hens had undergone the painful process of beaksearing as well (Singer and Mason 37). National Public Radio reports that about 7\% of the eggs produced in the United States are "cage-free," but the production process kills twice as many hens as the factory farmed system (Charles). Even "cage-free" operations often entail intense crowding that severely stresses chickens and fosters spread of disease. The well-being of "free ranging" chickens is also more difficult to monitor. Even backyard chicken operations are problematic. Male chicks who do not produce eggs are "culled," and hens who stop producing eggs after a year or two are often dumped. Farm Sanctuary reportedly receives almost 500 abandoned chickens each year from backyard operations (Aleccia).

Regardless of living conditions, it cannot be avoided that Nonhuman Animals raised for flesh will eventually go to slaughter. For Nonhuman Animals reared for their labor or products, direct death or indirect death following over-expenditure in egg, dairy, etc. production is also 
inevitable. In fact, labeling schemes rarely have anything to do with Nonhuman Animal welfare in the slaughtering process (Singer and Mason 67). Most "humanely raised" animals are transported in the same manner and slaughtered in the same slaughterhouses as "factory farmed" animals. The move to humane products continues to support institutional exploiters and involves no goal of abolishing exploitation. "Humane" production is thus inherently contradictory to the supposed desire of "humane" producers to respect the interests of other animals. Applying a Marxist critique of capitalist exploitation to the Nonhuman Animal industry, Torres reminds us that incorporation into the capitalist machine inevitably creates vulnerability: "The moment we use another being instrumentally, we have denied that being its [sic] right to exist on its [sic] own terms ..." (Torres 27). The use of Nonhuman Animals is not a relevant issue, only their treatment. Supposedly more humane use becomes an added value that can elicit greater profit. For instance, Llano Seco Rancho advertises on their website: "You can feel good about buying our certified organic pork for your family." With these alternative systems, consumers can pay extra for peace of mind despite the fact that welfare is actually undermined. "Humaneness" becomes commodified. Instead of a moral imperative, it becomes a product to be capitalized on:

Though some producers will be slow to come along, the industry operates on thin enough margins that it will recognize a market opportunity when it sees it, and happily provide alternatives for people of conscience, provided it can reasonably profit from those alternatives. (Torres 100)

Stories which paint idyllic images of happy, willing, and grateful Nonhuman Animals are likely a reaction to Nonhuman Animal rights mobilization, yet this reaction works to compromise public discomfort with Nonhuman Animal use in a way that protects business (Adams 20). Humane rhetoric abates consumer qualms with comfortable and pleasant company images intended to increase sales: 
Our girls spend an absurd amount of time singing and chatting. Each day begins with a stretch, a wing flap, (and for some an attempted flight). The remainder of the day consists of gab, chat, gossip, singing, and blather. If they are not eating, drinking, or egg-laying, they are singing. The amount of chicken chat in our barns is downright ridiculous. We have no idea what they are trying to tell one another, and we are even less certain they are actually listening to each other, but we do know that they are thoroughly enjoying themselves. (Pete \& Gerry's Organic Eggs) ${ }^{6}$

This narrative, typical of many humane products, erases the notion of the Nonhuman Animal as a victim, as is typical with factory farming. Instead, the consumer might be persuaded to continue or increase Nonhuman Animal product consumption if it is thought that the animals are not only living in more humane conditions, but are actually "enjoying themselves." Instead of understanding the purchase of Nonhuman Animal products as a means of causing those animals harm, it is actually framed as a means of helping them. If purchasing these products is thought as more than just harmless, but as a means of actually creating happiness, surely consumers would be encouraged to purchase even more.

These stories are essentially marketing ploys. As we have seen, they are generally untruthful and unverified. As several anti-welfare Nonhuman Animal advocacy organizations have argued: "Positive-sounding labels are guaranteed to increase sales of more expensive 'humane' products, but the evidence suggests that this is where the guarantees end" (Humanemyth.org). Hence, the humane movement remains at its heart an economic enterprise that continues to profit from the oppression of Nonhuman Animals. This alternative food industry, then, fails to challenge Nonhuman Animal use, and instead exploits public concern with Nonhuman Animal suffering and death. As ethicist Tom Regan explains, for a self-aware subject-of-life, deprivation is considered a harm and thus depriving a sentient being of life is considered a harm (Regan 243). Francione adds that it is more than a matter of deprivation; Nonhuman Animals actually have an interest in continuing to exist, just as humans do 
(Francione, Introduction 137). If we are concerned about the suffering of Nonhuman Animals, it should follow that we consider that death is also a harm and should not be imposed on other animals.

The humane product movement reflects the public concern with Nonhuman Animal suffering that is promulgated by decades of Nonhuman Animal welfare advocacy. By not insisting that it is actually the use itself that is problematic, consumers can be assuaged that using other animals is acceptable as long as suffering is reduced or seemingly eliminated. In some cases, the public is unaware that Nonhuman Animals are suffering at all (Kellert 177). ${ }^{7}$ Nonhuman Animal suffering is often rendered invisible. This is generally accomplished through industry advertising, media constructions, and other ideological constraints (Nibert, Animal Rights/Human Rights 13). Suffering is made relevant only when it is marketable. Because Nonhuman Animal production necessitates death, death is never considered a harm. Nonhuman Animal welfare organizations often promote this misnomer (that suffering can be eliminated from use and that death itself is not harm), ${ }^{8}$ presumably because to suggest that death is a harm would pose a direct challenge to the state and the industries that support them. Calls for radical structural change are oppositional to a professionalized non-profit that relies on fundraising for survival in a competitive, resource-scarce social movement arena.

Thus, there is an inherent contradiction created when managing the values-based labeling of products within a capitalist framework (Johnston 230; Allen \& Martin 221; Goodman 215). The nature of capitalism creates a tension between the desire to create ethically-sound products and the desire for competitive edge and profit. Added value and ethical practices can be commoditized, but the competitiveness of capitalism and the subsequent "race to the bottom" often means that compromises will be made. The availability of more easily accessible, cheaper, 
less ethical products also puts pressure on value-based labeling. For example, Turtle Mountain Company, a producer of vegan frozen desserts, claims that they cannot afford to purchase fairtrade chocolate (Harper 17). Presumably, the presence of countless other larger companies dilutes interest in Turtle Mountain Company, limiting their ability to add value to their products despite their interest in doing so. Likewise, the genuineness of the producers' commitment to Nonhuman Animal welfare will necessarily come into question when profits are involved. Furthermore, as the niche market for more responsible products increases, adherence to the initial moral vision will necessarily be challenged as the industry expands and diversifies (Raynolds \& Long 15). As more and more players enter the field, producers begin to stray from the original goals and bandwagon participators may corrupt labeling integrity. Some of this may be due to lack of cohesiveness that is more easily achieved and maintained in small groups, but some of this degradation may be due to lax regulations, regulatory loopholes, and producers who are prioritizing their own self interests (like the otherwise ethical vegan company Turtle Mountain Company that continues to use unethically sourced chocolate because it is cheaper). In the case of many fair-trade items, stores and unaffiliated entrepreneurs will generate their own labeling independent of any ethical regulations consumers might expect with the label. ${ }^{9}$ Certainly in Nonhuman Animal production, we have seen that labeling schemes lack regulation and are often found to be utterly irrelevant to the actual living and dying conditions of the Nonhuman Animals they represent.

Furthermore, the psychological impact this humane movement is having on a public concerned with the use of Nonhuman Animals should be questioned. Humane labels might assure consumers that the interests of Nonhuman Animals are being adequately addressed. This could create a social comfort with Nonhuman Animal use that ultimately dismantles any genuine 
concern for Nonhuman Animal welfare (Francione, Animals as Persons 16). Swayed by romanticized narratives, convincing labeling, and legitimizing governmental reform, consumers often unquestioningly assume necessary changes have been made to dysfunctional food systems (Raynolds). This can create complacency with any concern over humanity's moral obligation to other animals and can actually entrench morally problematic systems: "Such promotion [of supposedly humane Nonhuman Animal products] may actually increase consumption by people who had stopped eating animal products because of concerns about treatment and will certainly provide as a general matter an incentive for continued consumption of animal products" (Francione, Animals as Persons 16). As many Nonhuman Animal rights organizations are demonstrating, the reality of humane products runs contrary to the myth that is sold. The move to more humane products might be squashing questioning or dissent regarding its truthfulness. If the public thinks the problem is resolved and Nonhuman Animal advocacy organizations--the very organizations that are expected to represent the best interests of other animals--are advocating reforms and values-based labeling while celebrating reforms once secured, the public might not be expected to have any cause for alarm.

As of yet, no academic research has been conducted to determine how the promotion of humane products may actually increase the consumption of other animals. However, one could question why Nonhuman Animal industries would spend considerable resources promoting the improved "humaneness" of their products if it were not successful in increasing sales. A recent Meat Science report noted that increased concern over Nonhuman Animal welfare did not deter purchasing (Grimshaw, Miller, Palma and Kerth 444). Those who care about Nonhuman Animal well-being simply switch to higher "welfare" products when they can afford it. Whole Foods, one of the primary marketers of such products, has enjoyed tremendous growth following this 
trend. Indeed, Whole Foods has been a major actor in the facilitation of this trend as well. As a grocery business, Whole Foods has an interest in selling more Nonhuman Animal products; celebrating the "naturalness" and "humaneness" of their products is an important advertising tool. Whole Foods uses the public interest in Nonhuman Animal suffering to create a market for their supposedly superior products. They use "humaneness" to differentiate their products and give their company a competitive edge. Research in the "beef" market, for instance, shows that concerns over quality, healthiness, and innovativeness are some of the top factors for increasing the demand for cows' flesh (Schroeder and Mark 5). Producers and retailers are simply using the rhetoric of "humaneness" to address these consumer concerns and increase sales. Furthermore, the humane product movement not only creates a new market for Nonhuman Animal exploitation, but it also encourages vegans and vegetarians to resume their participation in that exploitation (Lennon; Raphael). If individuals give up Nonhuman Animal products because they are concerned with the suffering of other animals (and have not been convinced that death itself is a harm), and they can be convinced that the rise in "humane" labeling has addressed that suffering, those individuals will often recidivate.

\section{Professionalized Nonhuman Animal Rights and the Non-Profit Industrial Complex}

The overlapping agendas of the humane product movement and the professionalized Nonhuman Animal welfare movement is a major facilitator of this welfare failure. Several Nonhuman Animal welfare organizations work directly with labeling schemes for humane products. Compassion over Killing, for example, operates a long-standing campaign for the reformation of Animal Care Certified labeling (Compassion over Killing). The American Society for the Prevention of Cruelty to Animals (ASPCA), the Humane Society of the United 
States (HSUS), and over 30 other animal rights organizations are partners or supporters of Humane Farm Animal Care, an organization which certifies humane treatment (Humane Farm Animal Care). HSUS encourages consumption of "higher welfare animal products" to “... prevent abuses of animals occurring every day in factory farms" (HSUS "Humane Eating"). In this way, the HSUS and other advocacy organizations divert attention from the oppressive conditions that Nonhuman Animals continue to experience under the "humane" labels they promote.

This collaboration has been attributed to the Nonhuman Animal rights movement's adoption of what Francione has labeled "welfarism" (Francione, Rain Without Thunder 1) As the dominant ideology of the movement, welfarism is distinguished by its strategy of regulation and reform: “... the ethic which has emerged in mainstream society does not say we should not use animals or animal products. It does say that the animals we use should live happy lives where they can meet the fundamental set of needs dictated by their natures and where they do not suffer at our hands" (Rollin, "Animal Production and the New Social Ethic for Animals" 81). Welfarism and subsequently, the professionalized Nonhuman Animal "rights" movement, focuses on suffering instead of use. Major organizations understandably see collaboration with alternative food systems as an opportunity to reduce suffering.

Francione's abolitionist theory of Nonhuman Animal rights, however, argues that the movement's preference for welfarism does not reduce suffering in any significant way (Francione, Rain Without Thunder 119). For example, while the modification of confinement might make life for Nonhuman Animals slightly less uncomfortable, the suffering reduced is ultimately quite trivial in relation to the immense suffering and eventual death that remains unaddressed by welfarist reform. ${ }^{3}$ Again, the regulation of Nonhuman Animal use likely has the 
psychological effect of making human consumers more comfortable with the exploitation of Nonhuman Animals (Francione, Animals as Persons 16). Therefore, as long as Nonhuman Animal use itself remains unquestioned, the welfarist goal of reducing suffering and increasing overall humaneness is not likely be achieved. As abolitionist theorist Bob Torres reasons: “... we cannot hope to produce a world that is free of animal suffering and exploitation by promoting gentler forms of suffering" (Torres 135). Farm Sanctuary, an organization that favors welfare reform, has countered abolitionist claimsmaking by suggesting that welfare reform does increase public concern with Nonhuman Animals and will increase vegan and vegetarian numbers (Cooney). The stagnated growth in vegan numbers (DeCoux 9) and the exponentially increasing number of Nonhuman Animals exploited and killed for food despite decades of welfare reform might suggest otherwise.

Furthermore, Francione notes that most regulation has been imposed only when economically beneficial to the institutional exploiters (Francione, Rain Without Thunder 97). The passage of the Humane Slaughter Act of 1958 (amended in 1978) proceeded with the support of producers, as it improved efficiency by reducing carcass damage and worker injury (Francione, Rain Without Thunder page 95; U.S. Congress, "Ms. Temple Grandin" 13; U.S. Congress, "Emily F. Gleockler" 34). The vice president of the American Meat Institute reported that his organization was urging the approval of this legislation: "The experience of our members has been that humane slaughter methods are efficient methods. They result in improved productivity ..." (U.S. Congress, "Emily F. Gleockler" 6). Likewise, People for the Ethical Treatment of Animals (PETA) and HSUS have promoted the controlled atmosphere killing of chickens as profitable to producers through increased production capacity, affordability, improved working conditions, improved food quality, shelf-life, and safety, and reduced carcass damage and labor 
costs (Francione, "PETA and KFC"; HSUS, "Report"; HSUS, An HSUS Report 1; HSUS, "The Welfare of Birds at Slaughter"; PETA 4). The push to end castration, too, is marketed as a profitable move for ranchers. It is argued that failing to castrate will result in faster growth, shaving approximately three months from the raising process at an increased profit to ranchers (Rollin, "Food Animals"). In many cases, therefore, Nonhuman Animal advocacy organizations are striving to reduce suffering with the effect of increasing the efficiency of exploitative institutions; our moral concern for other animals becomes enmeshed with the desires of profitdriven institutional exploiters. This collaboration between professionalized Nonhuman Animal rights organizations and alternative animal-based systems ignores the underlying oppressive structures that allow Nonhuman Animals to be viewed as commodities in the first place. This oversight has the potential to increase use by promoting so-called "humane" systems, increasing public comfort with oppression, and increasing the efficiency of their institutionalized oppression. If the welfare-focused Nonhuman Animal rights movement is hoping to reduce suffering, these contradictions should be cause for alarm.

It is possible that the professionalized nature of the Nonhuman Animal rights movement has some responsibility to bear for the shortcomings of welfare reform. To secure itself in an unstable environment with fluctuating resources, organizations often professionalize to secure a space within the volatile social movement arena (McCarthy and Zald 20). There is a price to be paid for this security however. Organizations must legitimate themselves with state institutions and the public to maintain a protected and tolerated presence. This often entails a significant compromise of movement goals (Edwards and Marullo 136). It is easier to gain legitimacy from government institutions when a social movement works to reform the structure rather than 
dismantle it. It also means that organizations are thrust into competition for this legitimacy, which fragments the movement and further incentivizes tactical moderation (Smith 10).

Unfortunately for Nonhuman Animals, this generally means that the oppressive structures of capitalist enterprise become further entrenched as the social movement's cooperation actually further legitimates the system. Under this arrangement, the non-profit becomes a means of controlling dissent and diluting radical claimsmaking (Gilmore 45; Rodríguez 23; Smith 7). An industrial complex is created where for-profit industries work in tandem with social change organizations with state sanction and subsequent legal protection. Elite-run exploitative industries enjoy a more relaxed relationship with social change organizations (often earning their approval by complying with minor demands), while the organizations aiming for these smaller changes find that "victories" are much more easily obtained (a necessity in a highly competitive social movement environment). The benefit to industries is the improved public image and increased operational efficiency; the benefit to social change organizations is a steady stream of successes to fundraise behind (Torres, Making a Killing 93). The cost of this cooperation for Nonhuman Animals is that organizations intentionally choose non-confrontational claimsmaking (Freeman, "Framing Animal Rights in the 'Go Veg' Campaigns of U.S. Animal Rights Organizations" 163) and abandon their goal for abolition, which is often reframed as utopian or unachievable (Francione, Rain Without Thunder, 147).

An important characteristic of non-profit co-optation is that the pay and status of professional activists relies on the continuation of the system as it is. The mutually beneficial status-quo system is one that is perpetually producing service-needy oppressed individuals, and one that rewards organizations for their complacency with providing social service work and diminishing radical activism. Organizations and professionalized activists are encouraged to, “... 
suppress potential opposition from community members-no matter how illogical, exploitative, and unjust the system is" (Kivel 139). Jack Norris of Vegan Outreach, for example, advises a shift away from promoting veganism, as veganism is seen as "uptight" and "difficult" (Norris) Author Melanie Joy has framed abolitionist veganism as an unrealistic "all-or-nothing" approach (Joy, Strategic Action for Animals 63). Defending the welfare-oriented approaches of professionalized organizations like PETA and HSUS, James McWilliams also frames the abolitionist position as "the impossible dream," "utopian optimism," "childishly naïve," and the "radical fringe" (Williams). Matt Ball of Vegan Outreach and Bruce Friedrich of Farm Sanctuary also argue against the explicit promotion of veganism, instead suggesting the promotion of reduced Nonhuman Animal product intake (Ball and Friedrich 56). They seek to reduce suffering, not eliminate suffering per se. This focus on social services, that is, the focus on alleviating immediate suffering without working to end the structural sources of that suffering, characterize non-profits caught within the industrial complex. The focus on Nonhuman Animals who are suffering "right now," rather than prioritizing long-term systemic restructuring demonstrates that Nonhuman Animal non-profits work as a public-funded means of alleviating the dysfunctions of an unsustainable capitalist state. Non-profits are held responsible for maintaining an inefficient system by working to alleviate the immediate suffering caused by exploitative industries and the states that support them. Non-profits, and subsequently, the public, are taking up the state's slack (Wolch 206). And they do it under strict governmental monitoring and extremely limited funding, making them a particularly valuable and efficient state resource. Non-profits are rewarded for this societal function with a relatively peaceful existence within the state and legitimized operation and access to funding, thereby discouraging them from pursuing the necessary structural change to prevent Nonhuman Animal suffering from 
occurring in the first place. In maintaining this unjust and violent system, the non-profit industrial complex reproduces a "dialectic of death" (Rodríguez 37). The continued existence of oppression and suffering becomes reframed as natural and inevitable, something we can only hope to alleviate, not end (Gilmore 43).

\section{Abolitionism and Potential Compromises for Alternative Food Systems}

Welfare reform may be the dominant approach within Nonhuman Animal rights activism, but it is not the only approach. Within the discourse and collective action, there are a number of radical approaches that reject the use of other animals as well as their suffering. Not surprisingly, then, these factions also reject professionalization and its affiliated compromises. The No Kill movement, for instance, recognizes that death is a harm, and seeks to end "euthanasia" practices in favor of adoption (Winograd $\mathrm{x}$ ). This faction also operates at the grassroots level and is largely critical of large professionalized organizations. The "direct action"/ liberation faction also sees death as a harm and seeks to end use. However, this faction not only rejects professionalized organization, but maintains a preference for illegal tactics, which has made it a target of state repression (Lovitz 47). Like the direct action faction, abolitionism also concerns itself with institutionalized Nonhuman Animal exploitation and professionalization, but it favors legal, nonviolent means for challenging oppression. Some have suggested that the factional divides within the Nonhuman Animal rights movement are illusionary (Cochrane, "Animal Welfare vs. Animal Rights"; Joy, "Our Voices, Our Movement"), yet, as we have seen, the various factions have very distinct claimsmaking and often have very different goals. Welfarism may or may not envision an end to use, and welfarism most certainly prioritizes different issues and advocates very different tactics than its radical counterparts. Factionalism is actually quite characteristic of 
social movements (Zald and Ash 328), and the Nonhuman Animal rights movement is certainly not immune (Wrenn, "Applying Social Movement Theory" 38). The ability to dismiss the validity of factionalism reflects the ideological control that professionalized Nonhuman Animal advocacy organizations harness. Professionalized non-profits act as intermediaries between state and elite interests and the public they seek to control, hence, the power these organizations harness grants them the ability to construct meaning and protect their political power through the marginalization of competing factions (Kivel 143). Abolitionism constructs a sharp criticism of both professionalized advocacy and its preferred tactic of welfare reform, making it especially unpopular (and subject to appropriation) (Wrenn, "Abolitionist Animal Rights" 440; Wrenn, “Applying Social Movement Theory” 38).

The abolitionist theory of Nonhuman Animal rights is based on the premise that Nonhuman Animals are functionally and legally property in human animal society (Francione Introduction 50). So long as Nonhuman Animals are considered property, their interests can always be overridden by human interests in situations of even the most minor conflict. Abolitionists do not advocate for equal rights between nonhuman and human animals, as Nonhuman Animals have different interests than human animals (Francione Introduction xxxi). Instead, abolitionists push for the equal consideration of Nonhuman Animals according to their interests as sentient beings (avoiding pain and not being used as a resource) (Francione, Introduction 135). ${ }^{10}$ Central to these specific requirements, it is recognized that Nonhuman Animals have the right not to be treated as property. Recognition of this right necessarily entails an abolition of the institutionalized Nonhuman Animal use and exploitation that perpetuates their property status. Likewise, abolitionist Nonhuman Animal rights theory recognizes and rejects societal speciesism. Following Regan's theory, it is understood that there are no meaningful 
differences between nonhuman and human animals that would justify unequal consideration: "The species of a sentient being is no more reason to deny the protection of this basic right than race, sex, age, or sexual orientation is a reason to deny membership in the human moral community to other humans" (Francione, "A Revolution of the Heart"). Thus, the abolitionist approach calls for a rejection of the property-status held by Nonhuman Animals, a rejection of speciesism, and equal consideration.

Abolitionism also entails a strict adherence to non-violence. Ahimsa, a rule of conduct borrowed from Jainism, Hinduism, and Buddhism, is often used to describe this notion within the abolitionist movement: "Ahimsa is the principle that we should not act violently toward others in our thoughts, speech, or action" (Francione, "Commentary"). Other abolitionists adopt the principle of non-violence as a matter of moral rationality (Wrenn, "Abolitionist Animal Rights" 442). Violence is seen as irrational for at least two reasons. ${ }^{11}$ First, fighting for peace is antithetical to the goal of a peaceful society. Second, violence has been shown to be ineffective as a social movement tactic (Chenoweth and Stephan 10). Subsequently, the abolitionist approach adopts veganism as a necessary baseline. Veganism challenges the property status of Nonhuman Animals and is also consistent with non-violence (Francione, "Commentary"). More than a diet, veganism is a political protest that rejects the consumption of Nonhuman Animal products of all kinds wherever possible.

Abolitionism requires a complete rejection of Nonhuman Animal consumption both directly (as food or fashion) and indirectly (as entertainment, companionship, or research subjects). In contrast to those dominant Nonhuman Animal welfare philosophies addressed in this article, abolitionist theory argues that it is inconsistent to strive for an end to Nonhuman Animal use while continuing to consume them. Recognizing that there is little defensible 
grounds for excluding Nonhuman Animals from moral concern (Regan xvi; Rollin, Animal Rights 49), ${ }^{12}$ abolitionists seek to extend equal consideration to Nonhuman Animals (Francione, Introduction 82). The principle of equal consideration recognizes that Nonhuman Animals, like human animals, have morally significant interests in not suffering and in not being used as resources (Francione, Introduction 82). Respecting Nonhuman Animals as objects of moral concern who have an interest in not suffering cannot logically include consumption, assuming that consumption necessarily entails harm. ${ }^{13}$ The use of Nonhuman Animals as resources, fatally or not, constitutes harm to the Nonhuman Animal whose interest lies in not experiencing use or suffering. Use of any kind generally entails some degree of suffering, vulnerability, and oppressiveness. While some have argued that Nonhuman Animals can be used without necessarily causing them harm (Cochrane, Animal Rights Without Liberation), others insist that use constitutes structural violence (Nibert, Animal Oppression \& Human Violence 11). Unlike many humans, other animals cannot generally consent to their being used. As moral patients (rather than moral agents), they cannot enter a social contract. The system of domestication further complicates any possibility of consent, as other animals are created by humans for humans and kept in a perpetual state of dependency.

Abolitionist Nonhuman Animal rights theory, then, is fundamentally opposed to modern agricultural food systems which commodify Nonhuman Animals for human consumption. Unlike reformist animal rights theory, as advocated by professionalized Nonhuman Animal welfare organizations, abolitionism is also opposed to supposedly more "humane" systems, as they continue to exploit and objectify other animals. I have argued that alternative food systems that strive to improve, but not eliminate, Nonhuman Animal use will inevitably fall short of achieving "humaneness" so long as Nonhuman Animals and their products are still considered 
"food" and the exploitative system itself remains intact. Whether industrialized or progressive, Nonhuman Animal agriculture continues to perpetuate the use of other animals, thus failing to seriously address their welfare. Abolitionist theory rejects the possibility that any degree of welfare reform can seriously address the interests of Nonhuman Animals. Instead, abolitionism promotes veganism as the optimal and necessary option in addressing Nonhuman Animal welfare. Some suggest that domestication is in some cases beneficial to Nonhuman Animals (Cochrane, Animal Rights Without Liberation; Rollin, “Animal Production” 74), but others argue that domestication is fundamentally oppositional to the welfare of other animals, as they remain property and thus largely dependent and extremely vulnerable (Nibert, Animal Oppression 11). ${ }^{14}$ Organizations advocating industry regulation often argue that immediate abolition is impossible. Therefore, any improvement is a step in the right direction (Francione and Garner 103). Supposedly, a slow encroachment of welfare reforms will reduce the demand for Nonhuman animal products by enlightening the public and increasing the cost of production (Cooney, 2012). However, abolitionism also rejects the wishful thinking of an immediate end to speciesism. Abolitionism advocates an alternative gradual approach to eliminating Nonhuman Animal use through educational measures that underscore the importance of veganism in reducing demand and, for some, dismantling capitalism (Elise 41; Nibert, Animal Oppression 270). Neither does abolitionism compromise with industries in ways that legitimize (and streamline) Nonhuman Animal use. Given the inaccuracies and shortcomings of current humane labeling schemes, abolitionism suggests than an adoption of humanely-raised Nonhuman Animal products would do very little, if anything, to alleviate known problems for welfare. The fundamental moral issue of exploiting and killing other animals remains largely unexamined in a welfarist framework. 
As an alternative, veganism has the potential to respect the inherent rights and welfare of Nonhuman Animals: "Veganism is the only way forward that does not trade off the interests of animals today in the vast hope of some bright future right down the road" (Torres 136). As we have seen, organizations that take the welfarist stance have criticized vegan abolitionism as utopian and impractical. However, veganism immediately removes an individual from their involvement in the perpetuation of Nonhuman Animal exploitation and reduces demand for Nonhuman Animal products. Fortunately, there is increasing acceptance of the legitimacy, safety, and benefits of the vegan diet (American Dietetics Association 748). The abstinence from Nonhuman Animal products is also recognized as beneficial for environmental sustainability (Goodland \& Anhang 15; Tidwell). In addition, there are increasing opportunities in growing vegan markets which could encourage the food industry to move towards vegan products (Goodland \& Anhang 16). Hence, with the continued animal welfare and environmental concerns of Nonhuman Animal agriculture and the positive trends in the vegan movement, there could be promise in the promotion of veganism as a viable solution.

It remains to be seen whether veganism as a movement can gain the size and strength necessary for social change. An important characteristic of abolitionist vegan mobilization is failure to professionalize. As we have seen, professionalization inevitably requires an organizational structure that prioritizes fundraising over radical social change. A grassroots model undermines the competitive nature of a professionalized social movement environment, which ultimately fractures the movement and leaves it vulnerable to industry cooptation. In protecting the purity of goals, however, a grassroots vegan movement will have difficulty garnering the resources and public presence that professionalized organizations enjoy. A grassroots abolitionist vegan movement will also have to overcome competing claims by 
alternative systems and the professionalized Nonhuman Animal welfare movement. With the benefit of resources and state sanctioning, powerful counterclaims by industry and organizations have the ability to reframe veganism as an impractical alternative (Wrenn, "Abolitionist Animal Rights" 448). Agricultural industry's ability to normalize speciesism and ostracize veganism by dominating meaning construction has been well-documented (Freeman, "This Little Piggy Went to Press" 79; Nibert, Animal Rights 113). Yet, the institution of speciesism also has an advantage in the co-optation of non-profit organization. State sanctioning of social movement activity generally pushes activists to professionalize (which entails moderation of goals and tactics) to protect their existence. Radical social movement actors are often criminalized, thus meeting with significant state resistance (Rodríguez 29). The Nonhuman Animal rights movement has witnessed this with the industry-funded push for the Animal Enterprise Terrorism Act that effectively criminalizes radical activism on behalf of other animals (Lovitz 47). The language of the act is vague enough that it could reasonably extend to include nonviolent vegan activism if pushed.

Professionalized organizations that rely on foundational grants also find themselves extremely limited in their claimsmaking and activities. Elites have the resources to shape society and to protect their interests by establishing foundations that support non-profits that are working in favor of those interests. For example, VegFund operates with the support of a grant provided by an undisclosed grantor. Their conservative advocacy and their collaboration with other professionalized organizations that they often promote and fund likely reflects their reliance on that grant money. The trend of professionalization among social movement organizations and the subsequent marginalization of radical claimsmaking tend to be characteristic of social movement organization (Piven and Cloward xv). It should be no surprise that professionalized organizations 
like PETA, Farm Sanctuary, Vegan Outreach, and HSUS shy away from vegan claimsmaking, instead focusing on welfare reform, harm reduction, and even the besmirching of veganism and abolitionism.

\section{Conclusion}

Modern Nonhuman Animal agriculture has been heavily criticized as severely detrimental to Nonhuman Animal welfare (Singer, Animal Liberation 95). In response to consumer concerns, alternative systems that tout goals of humaneness have proliferated. However, improved humaneness ultimately means little to the welfare of the Nonhuman Animals who continue to be used and killed in these alternative systems. The continued oppression of Nonhuman Animals in alternative food systems perpetuates the property status of Nonhuman Animals, undermining their interests in avoiding harm and death. Furthermore, the existence of these alternative systems might have the effect of increasing the consumption of Nonhuman Animal products if they obscure any criticisms or uncertainties the public might have previously held regarding Nonhuman Animal exploitation (Francione, Animals as Persons 16). The confusion over "humane" products is purposefully constructed in industry narratives, but it is also perpetuated by the mutually beneficial alignment between industry and Nonhuman Animal welfare organizations in an industrial complex that hinders social change and protects state and elite interests. Hence, I suggest that alternative systems could actually be exacerbating the very problems they set out to combat, given their insistence on continued use of Nonhuman Animals. For activists and consumers concerned with human moral obligation to nonhumans, the professionalization of Nonhuman Animal rights advocacy might be avoided in favor of radical, 
grassroots activism that avoids the debilitating non-profit industrial complex and prioritizes vegan abolitionism.

\section{Notes}

${ }^{1}$ This term has been capitalized to denote that other animals represent a distinct social group. In Who's Afraid of Post-Blackness?, Touré defends the capitalization of "Black":

I believe 'Black' constitutes a group, an ethnicity equivalent to African-American, Negro, or, in terms of a sense of ethnic cohesion, Irish, Polish, or Chinese. I don't believe that whiteness merits the same treatment. Most American whites think of themselves as Italian-American or Jewish or otherwise relating to other past connections that Blacks cannot make because of the familial and national disruptions of slavery. So to me, because Black speaks to an unknown familial/national past it deserves capitalization. (ix)

While Nonhuman Animals are a hugely diverse group and do not share societies, they are part of one group, that is, a group of sentient beings that is not human and is subject to human violence. Similarly, as we would not capitalize "white," as whites already enjoy social privilege, humans would not need capitalization, as their status is already greatly elevated.

${ }^{2}$ This number includes cattle, calves, hogs, sheep, turkeys, ducks, layer and broiler chickens based on 2012 USDA records. This number also includes rabbits, as estimated from a 2002 report for the USDA (Grannis 23). If male chicks killed in hatcheries are included, this number is about 17.7 billion (the total number of female broiler and layer chickens doubled to account for males) (USDA, Hatchery Production 4).

${ }^{3}$ This practice is also known as rape.

${ }^{4}$ Euphemisms have been placed within quotation marks.

${ }^{5}$ This report is no longer hosted online.

${ }^{6}$ Singer and Mason toured Pete and Gerry's Organic eggs and were surprised to find extreme crowding (about 20,000 birds per $60 \times 400$ foot shed) and no access to the outdoors:. Chickens were also subject to the traditional practice of beak-searing. This paints a decidedly different picture from the image portrayed in the company's advertising (See Singer and Mason 101).

${ }^{7}$ I would argue that this ignorance may be on the decline since the 1984 survey, given the prolonged presence of Nonhuman Animal claimsmaking and the rise of humane products. 
However, this position does still exist, as evidenced by the moral "shock" individuals experience upon learning of how Nonhuman Animals are treated in industry (Jasper and Poulsen 500).

${ }^{8}$ See PETA's promotion of the controlled-atmosphere killing of chickens, for example (PETA 4).

${ }^{9}$ One example of this was shown in the Compassion over Killing case against fraudulent "cagefree" labeling. Another example is seen in the controversy over Wysong's Vegan ${ }^{\mathrm{TM}}$ dog and cat food which was found to contain non-vegan ingredients (Lin). The company trademarked the name "Vegan" for their product, but also stated that "Vegan" was just the name, and did not imply that the actual product was vegan.

${ }^{10}$ Francione defines sentience as subjective awareness and the possession of interests or preferences. As Nonhuman Animals used in food production are subjectively aware and have an interest in avoiding the pain and death associated with their exploitation, they are considered sentient beings (Francione, Introduction 178).

${ }^{11}$ Nibert also argues that violence in human/human and human/nonhuman relationships is not inevitable, but is rather a behavior of domination that has been socially constructed as "normal" and "natural" to legitimize structural oppression and social inequality to the benefit of society's elites (Nibert, Animal Rights 205).

${ }^{12}$ Regan , for instance, argues that we cannot deny the interests of other animals because they are self-aware, autonomous subjects-of-life that have preferences and can intentionally pursue those preferences (Regan 243). They have interests in experiencing pleasure and avoiding pain. Regan, like Francione, argues that death constitutes a harm for animals (Francione, Introduction 137; Regan 243). An ethical theory, he insists, must account for a duty to both moral agents and moral patients. Suggesting that Nonhuman Animals have less inherent value because they lack particular human characteristics is an arbitrary assumption. Francione argues, for instance, that the same distinctions arbitrarily drawn between humans and other animals can often be applied to some humans. Some humans are more intelligent than others, some humans are more selfaware than others, some humans garner more affinity than others, etc., but we do not subsequently conclude that less intelligent, less self-aware, or less amiable humans can be denied moral standing (Francione, Introduction 91).

${ }^{13}$ Ethicist Peter Singer disagrees, arguing that death is not a harm for Nonhuman Animals (Singer, Practical Ethics 94). Therefore, consumption could theoretically take place without harming a Nonhuman Animal. Some forms of consumption might also be seen as not causing harm, such as consuming the flesh of animals killed on roadways or eggs from backyard chicken operations. As far as backyard chickens' eggs, the hens used are still sourced from hatcheries where millions of discarded male chicks are killed (Wells). Furthermore, hens become "spent" after a couple of years and shelters and sanctuaries become inundated with hundreds of these discarded birds each year. Chickens are still considered property, meaning that their well-being is wholly dependent upon the benevolence of their owners. Their property status is also seen as a 
form of structural violence (Nibert, Animal Oppression 11). Even for "road kill" and randomly collected unfertilized eggs, consuming these products reinforces the notion that these animals and their products are "food," they are objectified and a hierarchy of oppression and human supremacy is maintained.

${ }^{14}$ Domesticated animals are especially susceptible to infectious diseases as well as genetic manipulations that are often hazardous to their well-being. As property, they can also be legally maimed and even killed under the most trivial of circumstances. Abolitionists view domesticated animals as human creations who have been genetically and psychologically manipulated to have great difficulty in self-sufficiency or survival without human maintenance. These conditions of vulnerability and genetically-induced handicaps are considered major hindrances to Nonhuman Animal welfare (Hall 40). Importantly, the maintenance of domestication is ultimately the maintenance of a system of oppression and human supremacy, which is antithetical to the realization of Nonhuman Animal rights. Nibert refers to this relationship as a form of structural violence (Nibert, Animal Oppression 11).

Feral populations that are able to thrive without human domination might be considered free-living and not domesticates ("wild" horses of the American West, for example). The intentional reproduction of domesticated species by humans for humans would be considered problematic (breeding Chihuahuas, for example), however, as would the unmanaged reproduction of domesticated species that require human maintenance for survival (not spaying cats and dogs or allowing rabbits and goats to reproduce, for example).

\section{Works Cited}

Adams, Carol. The Pornography of Meat. New York: The Continuum International Publishing Group, Inc., 2003.

Aleccia, J. Backyard Chickens "Dumped at Shelters when Hipsters Can't Cope, Critics Say." NBC News Health. NBCNews.com, 7, July 2013. Web. 7, July 2013.

Allen, P. \& Martin K. "The Capitalist Composition of Organic: The Potential of Markets in Fulfilling the Promise of Organic Agriculture." Agriculture and Human Values 17 (2000): 221232.

American Dietetic Association. "Position Paper on Vegetarian Diets." Journal of the American Dietetic Association 103, 6 (2003): 748-765. 
American Grassfed Association. American Grassfed Association, n.d. Web. 12, Oct. 2010.

Ball, Matt and Bruce Friedrich. The Animal Activist's Handbook: Maximizing Our Positive Impact in Today's World. Brooklyn: Lantern Books, 2009.

Charles, D. "What the Rise of Cage-Free Eggs Means for Chickens." All Things Considered. National Public Radio, 1, July 2013. Web. 7, July 2013.

Chenoweth, Erica and Maria Stephan. Why Civil Resistance Works: The Strategic Logic of Nonviolent Conflict. New York: Columbia University Press, 2011.

Cochrane, Alasdair. Animal Rights Without Liberation: Applied Ethics and Human Obligations. New York: Columbia University Press, 2012.

-. "Animal Welfare vs. Animal Rights: A False Dichotomy." Centre for Animals and Social Justice, 15, Aug. 2013. Web. 21, Aug. 2013.

Cole, Matthew. 'From 'Animal Machines' to Happy Meat? Foucault's Ideas of Disciplinary and Pastoral Power Applied to 'Animal-Centred' Welfare Discourse.” Animals 1 (2011): 83-101.

Compassion over Killing. "“Animal Care Certified'-A Case of Animal Abuse and Consumer Fraud." Campaigns. Compassion over Killing, n.d. Web. 12, Oct. 2010.

Cooney, Nick. Welfare Reform and Vegan Advocacy: The Facts. Animal Rights 2012 National Conference, August 21. Washington, D.C.

DeCoux, Elizabeth. "Speaking for the Modern Prometheus: The Significance of Animal Suffering to the Abolition Movement." Animal Law 16, 1 (2009): 9-64.

Donaldson, Sue and Will Kymlicka. Zoopolis: A Political Theory of Animal Rights. Oxford: Oxford University Press, 2011.

Edwards, B. and S. Marullo. "In a Declining Social Movement: The Demise of Peace Movement Organizations in the End of the Cold War Era." American Sociological Review 60, 6 (1995): 908-927.

Elise, T. "Anti-Capitalism and Abolition." Confronting Animal Exploitation: Grassroots Essays on Liberation and Veganism. Ed. Kim Socha and Sarahjane Blum. Jefferson: MacFarland \& Company, Inc. Publishers, 2013. 22-43.

Farm Sanctuary. The Truth behind the Labels: Farm Animal Welfare Standards and Labeling Practices: A Farm Sanctuary Report. Watkin's Glen: Farm Sanctuary, 2009. 
Francione, Gary. Animals, Property, and the Law. Philadelphia: Temple University Press, 1995.

-. Rain without Thunder: The Ideology of the Animal Rights Movement. Philadelphia: Temple University Press, 1996.

-. Introduction to Animal Rights: Your Child or the Dog? Philadelphia: Temple University Press, 2000.

-. Animals as Persons: Essays on the Abolition of Animal Exploitation. New York: Columbia University Press, 2008.

—. "Commentary: Aspects of the Vegetarian/Vegan Debate." The Abolitionist Approach, 2009. Web. 12, Oct. 2010.

—. "PETA and KFC: 'No Differences of Opinion about how Animals Should be Treated." The Abolitionist Approach, 2008. Web. 12, Oct. 2010.

—. "A Revolution of the Heart." The Abolitionist Approach, 2009. Web. 12, Oct. 2010.

-. "The Abolition of Animal Exploitation." The Animal Rights Debate: Abolition or Regulation? Eds. Gary Francione and Robert Garner. New York: Columbia University Press, 2010: 1-102.

Francione, Gary and Robert Garner. The Animal Rights Debate: Abolition or Regulation? New York: Columbia University Press, 2010.

Freeman, Carrie Packwood. "This Little Piggy Went to Press: The American News Media's Construction of Animals in Agriculture." The Communication Review 12, 1 (2009): 78-103.

—. "Framing Animal Rights in the 'Go Veg' Campaigns of U.S. Animal Rights Organizations." Animals and Society 18 (2010): 163-182.

Gilmore, Ruth Wilson. "In the Shadow of the Shadow State." The Revolution Will Not Be Funded: Beyond the Non-Profit Industrial Complex. Ed. INCITE! Women of Color Against Violence. Cambridge: South End Press, 2007. 41-52.

Gillespie, Kathryn. "How Happy is Your Meat?: Confronting (Dis)connectedness in the 'Alternative' Meat Industry.” The Brock Review 12, 1 (2011): 100-128.

Goodland, Robert and Jeff Anhang. "Livestock and Climate Change: What if the Key Actors in Climate Change are ... Cows Pigs and Chickens?” World Watch (2009) Nov./Dec, 10-19.

Goodman, David. "Organic and Conventional Agriculture: Materializing Discourse and AgroEcological Managerialism." Agriculture and Human Values, 17 (2000): 215-219. 
Grandin, Temple. "Welfare of Cattle During Slaughter and the Prevention of Nonambulatory (Downer) Cattle." Journal of American Veterinary Medical Association, 219, 10 (2001): 13691397.

Grannis, J. U.S. Rabbit Industry Profile. U.S. Department of Agriculture, 2002. Web. 20, June 2013.

Grimshaw, K., R. Miller, M. Palma, and C. Kerth. "Consumer Perception of Beef, Pork, Lamb, Chicken, and Fish.” Meat Science 96, 1 (2014): 443-444.

Hall, Lee. On Their Own Terms: Bringing Animal-Rights Philosophy Down to Earth. Darien: Nectar Bat Press, 2010.

Harper, Breeze. 'Race as a 'Feeble Matter' in Veganism: Interrogating Whiteness, Geopolitical Privilege, and Consumption Philosophy of 'Cruelty-Free' Products." Journal for Critical Animal Studies 8, 3 (2010): 5-27.

Humane Farm Animal Care. "Our Humane Society Partners." About: Who's Involved? Humane Farm Animal Care, n.d. Web. 12, Oct. 2010.

Humanemyth.org. “Choices.” FAQs. Humanemyth.org, n.d. Web. 12, Oct. 2010.

Humane Society of the United States. An HSUS Report: The Economics of Adopting Alternative Production Practices to Electrical Stunning Slaughter of Poultry. Humane Society of the United States, n.d. Web. 12, Oct. 2010.

—. "Humane Eating." Issues. Humane Society of the United States, n.d. Web. 11 Dec. 2013.

-. The Welfare of Birds at Slaughter. Humane Society of the United States, 2009. Web. 12 Oct. 2010.

Jasper, James and Jane Poulsen. "Recruiting Strangers and Friends: Moral Shocks and Social Networks in Animal Rights and Anti-Nuclear Protests." Social Problems 42 (1995): 493-512.

Johnston, Josée. "The Citizen-Consumer Hybrid: Ideological Tensions and the Case of Whole Foods." Theory and Society 37 (2008): 229-270.

Joy, Melanie. Strategic Action for Animals: A Handbook on Strategic Movement Building, Organizing, and Activism for Animal Liberation. Brooklyn: Lantern Books, 2008.

-. "Our Voices, Our Movement: How Vegans Can Move Beyond the 'Welfare-Abolition Debate." One Green Planet, 2012. Web. 21, Aug. 2013.

Kellert, Stephen. "American Attitudes toward a Knowledge of Animals: An Update." Advances in Animal Welfare Science 1 (1984): 177-213. 
Kivel, Paul. "Social Service or Social Change?" The Revolution Will Not Be Funded: Beyond the Non-Profit Industrial Complex. Ed. INCITE! Women of Color Against Violence. Cambridge, MA: South End Press, 2007. 129-149.

Lennon, Christine. "Why Vegetarians are Eating Meat." Food \& Wine. American Express Publishing, 2007. Web. 20, Aug. 2013.

Lin, Doris. "More Non-Vegan Vegan Products." About.com Animal Rights, 2013. Web. 21, Aug. 2013.

Llano Seco Rancho. Why Choose Llano Seco? Llano Seco Rancho, n.d. Web. 12, Oct. 2010.

Lovitz, Dara. Muzzling a Movement: The Effects of Anti-Terrorism Laws, Money \& Politics on Animal Activism. Brooklyn: Lantern Books, 2010.

McCarthy, John and Mayer Zald. The Trend of Social Movements in America: Professionalization and Resource Mobilization. Morristown: General Learning Press, 1973.

McWilliams, James. "Radical Activism and the Future of Animal Rights." Pacific Standard, 2013. Web. 3, July 2013.

Nibert, David. Animal Rights/Human Rights: Entanglements of Oppression and Liberation. Oxford: Rowman and Littlefield, 2002.

-. Animal Oppression and Human Violence: Domesecration, Capitalism, and Global Conflict. New York: Columbia University Press, 2013.

Nierenberg, D. \& Garcés, L. (2004). Industrial Animal Agriculture - The Next Global Health Crisis? London: World Society for the Protection of Animals.

Norris, Jack. Does Veganism Spread Itself? Vegan Outreach, 2009. Web. 26, Feb. 2012.

Organic Valley. "Humane Animal Treatment: A Cornerstone of Organic." Why Organic? Animal Care. Organic Valley Family of Farms, n.d. Web. 12, Oct. 2010.

People for the Ethical Treatment of Animals. Controlled-Atmosphere Killing VS. Electric Immobilization: A Comparative Analysis of Poultry-Slaughter Systems from Animal Welfare, Worker Safety, and Economic Perspectives. Norfolk: People for the Ethical Treatment of Animals, 2007.

Pete \& Gerry's Organic Eggs. Our Organic Eggs. Pete and Gerry’s Organics, LLC., n.d. Web. 12, Oct. 2010.

Piven, Fraces and Richard Cloward. Poor People's Movements: Why They Succeed, How They Fail. New York: Pantheon Books, 1977. 
Raphael, Rina. "Some Vegetarians Beat a 'Humane' Retreat Back to Meat." Today.com, 2011. Web. 20, Aug. 2013.

Raynolds, Laura and Michael Long. "Fair/Alternative Trade." Fair Trade: The Challenges of Transforming Globalization. Eds. Laura Raynolds, Douglas Murray, and John Wilkinson. New York: Routledge, 2007. 15-32.

Raynolds, Laura. "Patterns of Resistance." Globalization and Socio-Economic Restructuring. Lecture. Fort Collins: Colorado State University. Lecture. 2, Dec. 2009.

Regan, Tom. The Case for Animal Rights. Berkeley: The University of California Press, 2004.

Rodríguez, Dylan. "The Political Logic of the Non-Profit Industrial Complex." The Revolution Will Not Be Funded: Beyond the Non-Profit Industrial Complex. Ed. INCITE! Women of Color Against Violence. Cambridge: South End Press, 2007. 21-40.

Rollin, Bernard. "Animal Production and the New Social Ethic for Animals." Journal of Social Philosophy 25, s1 (1994): 71-83.

—. Animal Rights \& Human Morality. Amherst: Prometheus Books, 2006.

—. "Food Animals." Animal Rights Seminar. Fort Collins: Colorado State University. Lecture. 19, Nov. 2009.

Schroeder, T. and D. Mark. "How Can the Beef Industry Recapture Lost Consumer Demand?" Journal of Animal Science 77 (2000): 1-13.

Singer, Peter. Animal Liberation: A New Ethics for our Treatment of Animals. New York: Random House, 1975.

—. Practical Ethics. Cambridge: Cambridge University Press, 1999.

Singer, Peter and Jim Mason. The Way We Eat: Why Our Food Choices Matter. Rodale, 2006.

Smith, A. "Introduction." The Revolution Will Not Be Funded: Beyond the Non-Profit Industrial Complex. Ed. INCITE! Women of Color Against Violence. Cambridge: South End Press, 2007. $1-18$.

Steinfeld, Henning, Pierre Gerber, Tom Wassenaar, Vincent Castel, Mauricio Rosales, and Cees de Haan. Livestock's Long Shadow: Environmental Issues and Options. Rome: Food and Agriculture Organization of the United Nations, 2006.

Thompson, Alice. "Harpoon-Caught Swordfish." Whole Story: The Official Whole Foods Market Blog. Whole Foods, 2012. Web. 21, Aug. 2013. 
Tidwell, Mike. "The Low-Carbon Diet.” Audubon Magazine, 2009. Web. 20, July 2009.

Torres, Bob. Making a Killing: The Political Economy of Animal Rights. Oakland: AK Press, 2007.

Touré. Who's Afraid of Post-Blackness? What It Means to Be Black Now. New York: Free Press, 2011.

United States Congress. "Statement of Ms. Temple Grandin, Livestock Editor, Arizona Farmer and Rancher." Hearing before the Subcommittee on Livestock and Grains of the Committee on Agriculture on H.R. 1464. 95 ${ }^{\text {th }}$ Cong., $2^{\text {nd }}$ sess., (pp. 13-16). Washington: GPO, 1977.

-. "Statement of Emily F. Gleockler, Executive Secretary of Humane Information Services, Inc." Hearing before the Subcommittee on Livestock and Grains of the Committee on Agriculture on H.R. 1464. 95 ${ }^{\text {th }}$ Cong., $2^{\text {nd }}$ sess., (pp. 34-36). Washington: GPO, 1977.

United States Department of Agriculture. Chickens and Eggs 2012 Summary. U.S. Department of Agriculture, 2013. Web. 20, June 2013.

—. Livestock Slaughter 2012 Summary. U.S. Department of Agriculture, 2013. Web. 28, June 2013.

—. Poultry Slaughter 2012 Summary. U.S. Department of Agriculture, 2013. Web. 20, June 2013.

—. Hatchery Production 2012 Summary. U.S. Department of Agriculture, 2013. Web. 20, June 2013.

United States Environmental Protection Agency. "National Pollutant Discharge Elimination System Permit Regulation and Effluent Limitation Guidelines and Standards for Concentrated Animal Feeding Operations (CAFOs); Final Rule.” Federal Register 68.29, 2003.

Wells, Christine. "What's Wrong with Backyard Eggs?” Gentle World, n.d. Web. 21, Aug. 2013.

Winograd, Nathan. Redemption: The Myth of Pet Overpopulation and the No Kill Revolution in America. Los Angeles: Almaden Books, 2007.

Wolch, Jennifer. The Shadow State: Government and Voluntary Sector in Transition. New York: Foundation Center, 2006.

Wrenn, Corey. "Abolitionist Animal Rights: Critical Comparison and Challenges within the Animal Rights Movement. Interface: A Journal for and about Social Movements, 4, 2 (2012): 438-458. 
-. "Applying Social Movement Theory to Nonhuman Rights Mobilization." Peace Studies Journal 5, 3 (2012): 27-44.

Zald, Mayer and Roberta Ash. Social Movement Organizations: Growth, Decay and Change. Social Forces, 44, 3 (1966): 327-341. 